ISSN : $2302-1590$

E-ISSN: $2460-190 \mathrm{X}$

ECONOMICA

Journal of Economic and Economic Education Vol.2 No.2 (152 - 164)

\title{
PERBEDAAN HASIL BELAJAR EKONOMI ANTARA MODEL PREDICTION GUIDEDENGAN MODEL KONVENSIONAL YANG DI LAKSANAKAN DI KELAS X SMA N 2 KOTO XI TARUSAN
}

\author{
Miky Mardianto \\ Mahasiswa Program Studi Pendidikan Ekonomi STKIP- PGRI Sumbar \\ Jl. Gunung Pangilun No.1, Padang Sumatera Barat \\ Email: micky.mm@yahoo.com
}

Submited: 2014.02.26 Reviewed: 2014.03.13 Accepted: 2014.04.12

http://dx.doi.org/10.22202/economica.2014.v2.i2.228

\begin{abstract}
This research begin from fact in School that uncapability of teacher in activating student which teacher always use discourse method to deliver lecture so that student await from teacher and do not feel to be challenged to master Iesson items. This research use experiment approach to see difference of learning outcomes of economics among prediction guide model and conventional model. From result of research seen that applying of Prediction Guide model in Economic subject give better learning outcome compared to learning otcome on Conventional model. This Matter can be seen from mean learn experiment class student 78,25 while class control 69,5. Based on statistic ttest have larger value compared to ttable that is ttest $=2.63>$ ttabel $=2,000$ alpha 0.05 hence Ho refused and Ha accepted, hence existence of significant difference of learning outcome using model study of Prediction Guide with conventional model on Economic subject of class of X SMA N 2 Koto XI Tarusan.
\end{abstract}

\begin{abstract}
Abstrak
Penelitian iniberawal dari kenyataan di Sekolah bahwa kurang mampunya guru dalam mengaktifkan siswa yang mana guru selalu memakai metode ceramah sehingga siswa menunggu dari guru dan tidak merasa tertantang untuk menguasai materi pelajaran dengan usaha sendiri.Penelitian ini menggunakan pendekatan eksperimen untuk melihat perbedaan hasil belajar ekonomi antara model prediction guidedengan model konvensional.Dari hasil penelitian terlihat bahwa penerapan pengggunaan model pembelajaran Prediction Guide pada mata pelajaran Ekonomi memberikan hasil yang lebih baik dibandingkan dengan hasil belajar yang hanya menggunakan model Konvensional. Hal ini dapat dilihat dari rata-rata belajar siswa kelas eksperimen 78,25 sedangkan kelas kontrol 69,5. Berdasarkan perhitungan statistik yang dilakukan didapat $t_{\text {hitung }}$ memiliki nilai yang lebih besar dibandingkan dengan dengan $t_{\text {tabel }}$ yaitu $t_{\text {hitung }}=2,63>t_{\text {tabel }}=2,000$ pada taraf nyata 0,05 maka hipotesis nol (Ho) ditolak sedangkan hipotesis alternatif (Ha) diterima, maka adanya perbedaan yang signifikan hasil belajar siswa yang menggunakan model pembelajaran Prediction Guide dengan model konvensional pada mata pelajaran Ekonomi kelas X SMA N 2 Koto XI Tarusan. Hal ini disebabkan karena pada kelas eksperimen siswa dibimbing untuk dapat mengembangkan kemampuan dan potensinya.

Keywords: prediction guide model, conventional model, learning outcome
\end{abstract}




\section{PENDAHULUAN}

Mutu pendidikan akan dapat ditingkatkan jika proses belajar mengajar telah sukses dilaksanakan. Selain itu, proses belajar mengajar juga mempunyai hal yang tak kalah pentingnya. Menurut Arsyad (2009:15) menyatakan bahwa "dalam suatu proses belajar mengajar, dua unsur yang amat penting adalah metode mengajar dan media pembelajaran". Dan kedua unsur tersebutlah yang sangat penting dalam proses belajar mengajar semua bidang ilmu.

Mengingat pentingnya peranan ekonomi, maka pemerintah terus mengusahakan meningkatkan kemampuan peserta didik dalam memahami konsep ekonomi.Keberhasilan peserta didik dalam mempelajari ekonomi dapat dilihat dari pemahaman konsep belajar siswa.Menurut yulaelawaty(2002:67) yang dimaksud dengan pemahaman konsep adalah : "salah satu perangkat standar program pendidikan yang merefleksikan kompetensi sehingga dapat mengantarkan siswa untuk menjadikompeten dalam berbagai bidang kehidupan. Untuk itu pemerintah banyak melakukan berbagai usaha, diantaranya melengkapi sarana dan prasarana serta melakukan penataran terhadap guru ekonomi itu sendiri, karena guru mempunyai peranan yang sangat penting dalam meningkatkan mutu pendidikan".

Kemampuan pemahaman konsep siswa yang kurang maksimal juga berpengaruh terhadap hasil belajar, karena hasil evaluasi siswa masih dibawah Kriteria Kentutasan Minimum (KKM) yaitu 70. Ini juga dapat dilihat dari data ujian mid semester I siswa kelas X SMA N 2 Koto Tarusan Tahun Ajaran 2012/2013 memperlihatkan hasil belajar yang rendah seperti pada tabel 1 berikut:

Tabel 1.Nilai Rata-Rata Ujian Mid Mata Pelajaran Ekonomi Kelas X Semester 1 di SMA N 2 Koto XITarusan Tahun Ajaran 2012/2013

\begin{tabular}{llllll}
\hline \multirow{2}{*}{ Kelas } & \multirow{2}{*}{ Nilai rata-rata } & $\begin{array}{l}\text { Siswa yang } \\
\text { tuntas }\end{array}$ & $\begin{array}{l}\text { Siswa yang } \\
\text { tidak tuntas }\end{array}$ & Y Ketuntasan & \\
\cline { 6 - 6 } & & 18 & 14 & 56,25 & Tidak \\
\hline X1 & 69 & 16 & 18 & 47,05 & 43,75 \\
X2 & 57 & 9 & 23 & 28,12 & 52,95 \\
X3 & 52 & 8 & 22 & 26,67 & 71,88 \\
X4 & 52 & 19 & 17 & 52,78 & 73,33 \\
X5 & 60 & 19 & &
\end{tabular}

Sumber: Guru mata pelajaran ekonomi kelas X di SMA N 2 Koto XI Tarusan.

Dari data di atas terlihat bahwa nilai ratarata ekonomi siswa rendah, nilai rata-rata yang diperoleh siswa kelas X SMA N 2 Koto XI Tarusan, dari 32 orang siswa di kelas X 1 hanya 18 orang yang tuntas dan 14 orang tidak tuntas, nilai rata-rata 69. Kelas X 2, dari 34 orang siswa hanya 16 orang siswa yang tuntas dan 18 orang tidak tuntas, dengan nilai rata-rata 57, dikelas $\mathrm{X}$ 3 dari 32 orang siswa hanya 9 siswa yang tuntas dan 23 orang tidak tuntas dengan nilai rata-rata 52 dan dikelas $\mathrm{X} 4$, dari 30 orang siswa hanya 8 orang yang tuntas dan 22 orang tidak tuntas dengan nilai rata-rata 52 dan kelas X 5, dari 36 siswa siswa hanya 19 orang siswa yang tuntas dan yang tidak tuntas 17 orang dengan nilai rata-rata 60. jadi nilai tersebut jauh di bawah Standar Ketuntasan Belajar Minimal (SKBM) yang telah ditetapkan oleh guru mata pelajaran ekonomi SMA N 2 Koto XI Tarusan yaitu 70,00.

Berdasarkan permasalahan di atas penulis tertarik untuk menerapkan strategi yang dapat meningkat kan hasil belajar siswa yaitu"strategi prediction guide (tebak pelajaran)", Strategi ini merupakan salah satu strategi yang tepat untuk mendorong siswa agar terlibat dalam proses pembelajaran secara aktif dari awal hingga 
akhir. Strategi ini juga sangat bermanfaat bagi pendidik dan peserta didik. Manfaatnya siswa dapat memahami tentang pembahasan yang akan di bahas seperti pembahasan tentang inflasi yang mana disitu siswa dituntut untuk mengeluarkan ide-idenya sehingga ide-ide tersebut akan tersalur dan juga akan tertanam dalam pikiran nantinya.

\section{Hasil Belajar}

Hasil belajar merupakan tolak ukur yang digunakan untuk menentukan tingkat pemahaman dan penguasaan seseorang terhadap pelajaran, yang mana berupa pengetahuan, keterampilan, nilai dan sikap setelah seseorang mengalami proses belajar. Dimyati dan Mudjino (2006:200), menjelaskan hasil belajar adalah tingkat keberhasilan yang dicapai oleh siswa setelah mengikuti suatu kegiatan pembelajaran, dimana tingkat keberhasilan tersebut ditandai dengan skala nilai berupa huruf, kata atau simbol.

Sedangkan Nasution (2009:61)

Menjelaskan "hasil belajar siswa dirumuskan sebagai tujuan instruksional umum (TIU) yang dinyatakan dalam bentuk lebih spesifik dan merupakan komponen dari tujuan umum mata kuliah atau bidang studi".

Menurut Benyamin Bloom dalam Sudjana (2009:22) Dalam sistem pendidikan nasional rumusan tujuan pendidikan, baik tujuan kurikuler maupun tujuan intruksional merupakan klasifikasi hasil belajar. Hasil belajar secara garis besar dibagi menjadi tiga ranah :

a. Ranah kognitif biasanya berkenaan dengan hasil belajar intelektual yang terdiri dari enam aspek, yaitu pengetahuan atau ingatan, pemahaman, aplikasi, analisis, sintesis dan evaluasi.

b. Ranah afektif berkenaan dengan sikap yang terdiri dari lima aspek yaitu penerimaan, jawaban atau reaksi, penilaian, organisasi, dan internalisasi.

c. Ranah psikomotorik berkenaan dengan hasil belajar keterampila dan kemampuan bertindak. Ada enam aspek psikomotor yaitu gerakan rileks, keterampilan gerakan dasar, kemampuan perspektual, keharmonisan atau ketepatan, gerakan keterampilan kompleks, gerakan aspiratif dan gerakan interprestatif.

Slameto (2010:2) menyatakan bahwa hasil belajar merupakan hasil pengalaman individu setelah melakukan interaksi dilingkungannya sebagai suatu proses dalam memperoleh suatu perubahan tingkah laku. Sedangkan menurut Mulyasa (2007:258) penilaian hasil belajar dalam KTSP (Kurikulum Tingkat Satuan Pendidikan) dapat dilakukan dengan penilaian kelas, tes kemampuan dasar, penilaian akhir satuan pendidikan dan sertifikasi, benchmarking, dan penilaian program.

a. Penilaian Kelas

Penilaian kelas dilakukan dengan ulangan harian, ulangan umum dan ulangan akhir. Ulangan harian dilakukan pada setiap selesai proses pembelajaran dalam kompetensi dasar tertentu. Ulangan umum dilakukan pada akhir semester. Dan ulangan akhir dilakukan pada akhir program pendidikan. Penilaian kelas dilakukan oleh guru untuk mengetahui kemajuan dan hasil belajar peserta didik, mendiagnosa kesulitan belajar, memberikan umpan balik untuk perbaikan proses pembelajaran, dan penentuan kenaikan kelas.

b. Tes Kemampuan Dasar

Tes kemampuan dasar dilakukan untuk mengetahui kemampuan membaca, menulis dan berhitung yang diperlukan dalam rangka memperbaiki program pembelajaran.

c. Penilaian akhir Satuan Pendidikan dan Sertifikasi

Pada setiap akhir semester dan tahun pelajaran diselenggarakan kegiatan penilaian guna mendapatkan gambaran secara utuh dan menyeluruh mengenai ketuntasan belajar peserta didik dalam satuan waktu tertentu.

\section{d. Benchmarking}

Benchmarking merupakan suatu standar untuk mengukur kinerja yang sedang berjalan, proses dan hasil untuk mencapai 
suatu keunggulan yang memuaskan. Untuk dapat memperoleh data dan informasi tentang pencapaian bencmarking tertentu dapat diadakan penilaian secara nasional yang dilaksanakan pada akhir satuan pendidikan.

e. Penilaian Program

Penilaian program dilakukan oleh Departemen Pendidikan Nasional dan Dinas Pendidikan secara kontinue dan berkesinambungan. Penilaian program dilakukan untuk mengetahui kesesuaian KTSP dengan dasar, fungsi dan tujuan pendidikan nasional, serta kesesuaiannya dengan tuntutan perkembangan masyarakat dan kemajuan zaman.

\section{Proses Belajar dan Pembelajaran}

Belajar merupakan proses perubahan tingkah laku berkat pengalaman dan latihan. Manusia telah banyak memulai proses belajar semenjak dilahirkan, telah banyak perubahan dan keterampilan hidup yang dimilikinya karena proses belajar. Belajar dapat mengembangkan potensi diri yang ada, yang dapat meningkatkan kualitas pribadi.

Belajar adalah suatu proses yang kompleks yang terjadi pada diri setiap orang sepanjang hidupnya (Arsyad 2009:1). Belajar dan pembelajaran mempunyai keterkaitan yang sangat erat dan tidak dapat dipisahkan.

Secara global, Ada beberapa faktor yang mempengaruhi belajar (Syah, 2009:145) yakni :

a) Faktor internal (faktor dari dalam diri siswa), yakni keadaan/ kondisi jasmani dan rohani siswa.

b) Faktor eksternal (faktor dari luar siswa), yakni kondisi lingkungan disekitar siswa.

c) Faktor pendekatan belajar yakni jenis upaya belajar siswa yang meliputi strategi dan model yang digunakan siswa untuk melakukan kegiatan pembelajaran.

Sedangkan Pembelajaran merupakan kegiatan yang bertujuan yang banyak melibatkan aktivitas siswa dan peran guru. Peran guru dalam pembelajaran terutama pembelajaran ekonomi bukan hanya sebagai infomator saja, guru juga berperan sebagai pembimbing dan harus menyediakan kondisi yang memungkinkan siswa untuk mengikuti proses belajar mengajar. Pembelajaran adalah : proses komunikasi antara pembelajar, pengajar, dan bahan ajar. Dapat dikatakan bahwa, bentuk komunikasi tidak akan berjalan tanpa bantuan sarana untuk menyampaikan pesan (Sanaky, 2009:3).

Sedangkan menurut Hamalik (2009:57) : "suatu kombinasi yang tersusun meliputi unsur-unsur manusiawi, material, fasilitas, perlengkapan dan prosedur yang saling mempengaruhi mencapai tujuan pembelajaran". Dan tujuan dari pembalajaran itu sendiri adalah tujuan yang hendak dicapai setelah selesai diselenggarakannya suatu proses pembelajaran yang disusun berdasarkan tujuan kurikulum yakni tujuan yang hendak dicapai oleh suatu program studi, bidang studi dan suatu mata pelajaran".

Mengajar merupakan suatu proses yang komplek bukan hanya sekedar penyampaian informasi dari seseorang guru kepada siswa. Tingkat keberhasilan belajar siswa biasanya diukur dalam bentuk angka atau skor yang diperoleh dari hasil evaluasi.Hasil belajar pada hakikatnya dikenal sebagai prestasi belajar yaitu hasil yang diperoleh berupa kesankesan yang mengakibatkan perubahan dalam diri setiap individu sebagai hasil dari aktivitas dalam belajar.Kalau perubahan tingkah laku adalah tujuan yang ingin dicapai dari aktivitas belajar, maka perubahan tingkah laku itulah salah satu indikator yang dijadikan pedoman untuk mengetahui kemajuan individu dalam segala hal yang diperolehnya di sekolah.

\section{Model Belajar}

Model adalah suatu cara yang digunakan untuk mencapai tujuan yang ditetapkan Djamarah (2010:19). Jadi model 
merupakan jembatan untuk mencapai tujuan mengajar dan hasil belajar yang baik.Model bagi seorang guru adalah jembatan untuk mencapai tujuan pembelajaran, sementara model bagi seorang siswa adalah jembatan untuk memudahkan belajar agar memperoleh hasil yang baik.

Sedangkan Menurut Slameto (2010:96) Model mengajar juga memiliki fungsi sentral dalam pembelajaran diantaranya yaitu sebagai alat atau cara untuk mencapai tujuan pembelajaran. Makin baik model yang dipakai, makin efektif pula pencapaian tujuan pembelajaran.Seorang guru dalam menyampaikan materi perlu memilih model mana yang sesuai dengan keadaan kelas atau siswa sehingga siswa merasa tertarik untuk mengikuti pelajaran yang diajarkan.Dengan variasi model mengajar dapat meningkatkan hasil belajar siswa.

Menurut pendapat Djamarah (2010:27) sebagai berikut: a) Berpedoman pada tujuan. b) Perbedaan individual anak didik.

c) Kemampuan guru. d) Sifat bahan pelajaran. e) Situasi kelas. f) Kelengkapan fasilitas. g) Kelebihan dan kelemahan model.

\section{Pembelajaran Konvensional}

Model yang masih sering digunakan oleh guru dalam proses belajar mengajar adalah model ceramah. Model ceramah adalah model yang boleh dikatakan model tradisional karena sejak dahulu sampai sekarang masih di gunakan oleh guru, model ini juga digunakan sebagai alat komunikasi penyampaian pelajaran secara lisan kepada peserta didik dalam berinteraksi namun penggunaanya sangat popular.Model yang lazim digunakan dirasakan sangat efektif dan sederhana. Model ceramah tergantung pada personal guru yakni suara, gaya bahasa, sikap, prosedur, kelancaran, keindahan bahasa dan keteraturan guru dalam memberikan penjelasan yang tidak dimiliki secara mudah oleh semua guru (Suryosubroto 2009:158).
Menurut Sanjaya (2008:148) bahwa model ceramah adalah suatu cara menyajikan pembelajaran melalui penuturan secara lisan atau penjelasan langsung kepada sekelompok siswa. Meskipun model ceramah ini sederhana dan mudah dilakukan namun model ini mempunyai kelemahan-kelemahan, menurut Wina kelemahan-kelemahan tersebut yaitu:

a. Materi yang dapat dikuasai siswa sebagai hasil dari ceramah akan terbatas pada apa yang dikuasai guru.

b. Ceramah yang tidak disertai dengan peragaan dapat mengakibatkan terjadinya kesalahan pelajaran.

c. Guru yang kurang memiliki kemampuan bertutur yang baik sering dianggap membosankan.

d. Melalui ceramah sangat sulit untuk mengetahui apakah seluruh siswa sudah mengerti.

e. Model ceramah tidak dapat memberikan kesempatan untuk berdiskusi memecahkan masalah sehingga proses penyerapan pengetahuannya kurang tajam.

f. Model ceramah kurang memberikan kesempatan kepada peserta didik untuk mengembangkan keberanian dalam mengemukakan pendapatnya.

g. Pertanyaan lisan dalam model ceramah kurang dapat ditangkap oleh pendengarnya apalagi menggunakan katakata asing.

Sedangkan menurut Suryosubroto (2009:160) model ceramah ini mempunyai kebaikan dan keburukan dalam pelaksanaannya.kebaikan dan keburukan model ceramah antara lain:

1. Kebaikan model ceramah

a. Guru dapat menguasai seluruh arah kelas sebab guru semata-mata berbicara langsung sehingga ia dapatmenentukan arah itu dengan jalan menetapkan sendiri apa yang akan dibicarakan.

b. Organisasi kelas sederhana, dengan berceramah persiapan guru satu-satunya adalah buku catatan dan bahan pelajaran, ada kemungkinan sambil duduk dan berdiri.

2. Keburukan model ceramah 
a. Guru sukar mengetahui sampai dimana murid-muridnya telah mengerti materi yang diajarkan.

b. Murid sering kali memberikan pengertian lain dari hal yang dimaksud guru, hal ini dapat disebabkan karena ceramah merupakan rangkaian kata-kata yang sewaktu-waktu dapat menimbulkan salah pengertian.

Dari uraian di atas dapat disimpulkan bahwa model ceramah memiliki kebaikan antara lain guru dapat menguasai seluruh arah kelas sehingga organisasi kelas menjadi sederhana karena dengan berceramah persiapan guru adalah buku catatan dan bahan ajar. Namun selain kebaikan, model ceramah juga memiliki beberapa keburukan antara lain guru sukar mengetahui sampai dimana tingkat pemahaman siswa mengenai materi yang diajarkan dan model ceramah juga menyebabkan anak didik menjadi pasif di kelas.

\section{Model Prediction Guide}

Prediction Guide terdiri dari dua kata yaitu prediction danguide.Dalam Echol (2003:443) prediction berarti ramalan, perkiraan atau prediksi.Sedangkan Guide dalam Echol (2003:125) berarti buku pedoman, panduan, menuntun atau mempedomani.Jadi, prediction guide berarti panduan atau penuntun prediksi. Hisyam (2007:4) mengartikan prediction guide sebagai tebak pelajaran.

Menurut Hisyam (2007:4) dalam melaksanakan model Prediction Guide ada beberapa tahap yang harus dilakukan sebagai berikut:

1. Penentuan topik harus disesuaikan dengan silabus.

2. Dalam pembelajaran dengan Prediction Guide siswa dibagi atas kelompok- kelompok kecil yang terdiri empat sampai lima orang siswa dengan kemampuan yang bervariasi.

3. Lembaran Prediction Guide yang berisikan sejumlah pernyataan dibagikan kepada masing-masing anggota kelompok dan langsung diisi oleh seluruh anggota kelompok. Setelah itu guru meminta perwakilan kelompok untuk menyalin isian Prediction Guide mereka sesuai prediksi dominan pada kelompok.

4. Guru mengawasi jalannya diskusi siswa.

5. Guru menunjuk salah satu kelompok untuk mempresentasekan hasil diskusi mereka tentang satu pernyataan dalam lembaran Prediction Guide.

6. Guru menjelaskan materi pelajaran secara interakif, sehingga siswa bisa meninjau kembali hasil prediksi mereka mengenai pernyataan yang ada pada lembaran Prediction Guide. Lalu guru menanyakan berapa prediksi siswa yang benar.

7. Guru memberikan penghargaan kepada kelompok yang prediksinya paling banyak mengena.

Berdasarkan kutipan tersebut, maka dalam penelitian ini peneliti menggunakan langkah-langkah model pembelajaran yang dinyatakan oleh Hisyam (2007:4). Dalam model prediction guide ini, siswa dituntut untuk lebih aktif di dalam proses belajar mengajar dan siswa diharapkan dapat terlibat dalam pembelajaran dari awal pertemuan sampai dengan akhir pembelajaran serta memiliki perhatian ketika guru menyampaikan materi.

\section{Hipotesis}

Berdasarkan kerangka konseptual di atas maka dapat dirumuskan hipotesis penelitian sebagai berikut:"Terdapat perbedaan hasil belajar ekonomi yang menggunakan model pembelajaran Prediction Guide dengan konvensional pada SMA N 2 Koto XI Tarusan".

Adapun rumusan hipotesisnya adalah :

$$
\begin{aligned}
& \text { Ho: } \mu_{1}=\mu_{2} \\
& \text { Ha }: \mu_{1} \neq \mu_{2}
\end{aligned}
$$

Keterangan :

$$
\begin{aligned}
& \mathrm{Ho}=\text { hipotesis o } \\
& \mathrm{Ha}=\text { hipotesis kerja } \\
& \mu_{1}=\text { nilai rata-rata kelas }
\end{aligned}
$$

eksperimen

$$
\mu_{2}=\text { nilai rata-rata kelas }
$$

kontrol 


\section{METODE PENELITIAN}

\section{Jenis Penelitian}

Berdasarkan permasalahan yang telah dikemukakan sebelumnya, maka jenis penelitian ini adalah penelitian eksperimen. Menurut Suharsimi (2006:

3) bahwa "penelitian eksperimen adalah penelitian yang dimaksud untuk melihat akibat dari suatu tindakan atau perlakuan". Caranya adalah dengan membandingkan satu atau lebih kelompok pembanding yang tidak diberi perlakuan.
Penelitian ini dilakukan terhadap dua kelompok yaitu kelas eksperimen dan kelas kontrol. Pada kelas eksperimen menggunakan strategi prediction guide dalam kegiatan pembelajaran, sedangkan pada kelas kontrol dengan pembelajaran yang biasa diberikan guru. Adapun rancangan penelitian yang digunakan adalah Random terhadap subjek, seperti yang digambarkan pada tabel 2

Tabel 2. Rancangan Penelitian

\begin{tabular}{lcc}
\hline Kelas & Perlakuan & Tes Akhir \\
\hline Eksperimen & $\mathrm{X}$ & $\mathrm{T}$ \\
Kontrol & - & $\mathrm{T}$
\end{tabular}

Sumber : Suharsimi (2006:87)

Keterangan :

$\mathrm{X}=$ Pembelajaran menggunakan strategi prediction guide

$\mathrm{T}=$ Tesakhiryang diberikan pada kedua kelas untuk melihat kemampuanpemahaman konsep setelah diberi perlakuan.

Data yang diolah dalam penelitian ini adalah data tes akhir yang diberikan kepada kedua kelompok sampel yang diberikan perlakuan yang berbeda.
Perbedaan hasil belajar kelas eksperimen dan kelas kontrol dapat terlihat pada tabel berikut :

Tabel 3. Distribusi Frekuensi Nilai Kelas Eksperimen di SMA N 2 Koto XI Tarusan

\begin{tabular}{llll}
\hline NO & Kelas Interval & Frekuensi & $\begin{array}{l}\text { Persentase } \\
(\%)\end{array}$ \\
\hline 1 & $50-57$ & 4 & 12,5 \\
2 & $58-65$ & 2 & 6,25 \\
3 & $66-73$ & 3 & 9,375 \\
4 & $74-81$ & 7 & 21,875 \\
5 & $82-89$ & 10 & 31,25 \\
6 & $90-97$ & 6 & 18,75 \\
JUMLAH & & $\mathbf{3 2}$ & $\mathbf{1 0 0}$ \\
MEAN & & $\mathbf{7 8 , 2 5}$ & \\
S & & $\mathbf{1 2 , 9 1}$ & \\
Maksimum & & $\mathbf{9 5}$ & \\
Minimum & & $\mathbf{5 0}$ & \\
\hline
\end{tabular}

Sumber: Pengolahan data primer 2013

Berdasarkan tabel 10, dapat diketahui bahwa data yang valid ada 32 buah dan tidak ada yang hilang. Meanadalah ratarata, mean dari skor adalah 78,25.Standar deviation, yaitu ukuran penyebaran data dari rata-ratanya, nilai standar deviasi dari skor kelas eksperimen adalah
12,91.Dengan nilai minimum sebesar 50 dan nilai maximum sebesar 95. Juga dapat dilihat bahwa skor terbanyak berada pada kelas ke-5 dengan interval 82-89 yaitu sebanyak 10 orang atau $31,25 \%$ dari keseluruhan subjek penelitian (32 orang). 


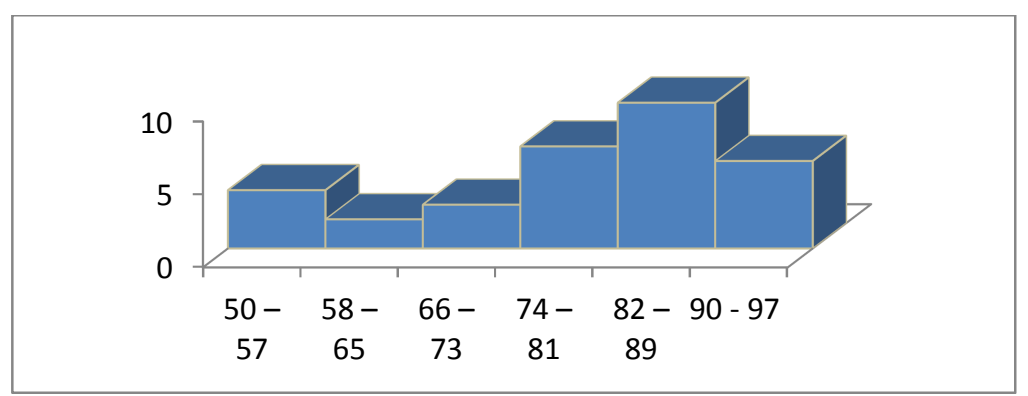

Gambar 1.Histogram Data Kelas Eksperimen

Berdasarkan gambar 1, juga dapat dilihat bahwa skor terbanyak berada pada kelas ke-5 dengan interval 82-89 yaitu sebanyak 10 orang dari keseluruhan subjek penelitian (32 orang)

Tabel 4. Distribusi Frekuensi Nilai Kelas Kontrol di SMA N 2 Koto XI Tarusan

\begin{tabular}{llll}
\hline NO & Kelas Interval & Frekuensi & Persentase (\%) \\
\hline 1 & $50-57$ & 6 & 20 \\
2 & $58-65$ & 9 & 30 \\
3 & $66-73$ & 4 & 13,33 \\
4 & $74-81$ & 4 & 13,34 \\
5 & $82-89$ & 4 & 13,33 \\
6 & $90-97$ & 3 & 10 \\
JUMLAH & & $\mathbf{3 0}$ & $\mathbf{1 0 0}$ \\
MEAN & & $\mathbf{6 9 , 5}$ & \\
S & & $\mathbf{1 3 , 2 9}$ & \\
Maksimum & $\mathbf{9 5}$ & \\
Minimum & & $\mathbf{5 0}$ & \\
\hline
\end{tabular}

Sumber: Pengolahan data primer 2013

Berdasarkan tabel 4, dapat diketahui bahwa data yang valid ada 30 buah dan tidak ada yang hilang. Meanadalah ratarata, mean dari skor adalah 69,5.Standar deviation, yaitu ukuran penyebaran data dari rata-ratanya, nilai standar deviasi dari skor kelas control adalah 13,29.Dengan nilai minimum sebesar 50 dan nilai maximum sebesar 95. Juga dapat dilihat bahwa skor terbanyak berada pada kelas ke-2 dengan interval 58-65 yaitu sebanyak
9 orang atau $30 \%$ dari keseluruhan subjek penelitian (30 orang).

Data hasil belajar berupa nilai untuk masing-masing siswa pada kelas eksperimen berjumlah 32 orang dan kelas kontrol berjumlah 30 orang.Nilai siswa pada kelas eksperimen berkisar antara 50 95, sedangkan pada kelas kontrol berkisar antara 50-95.

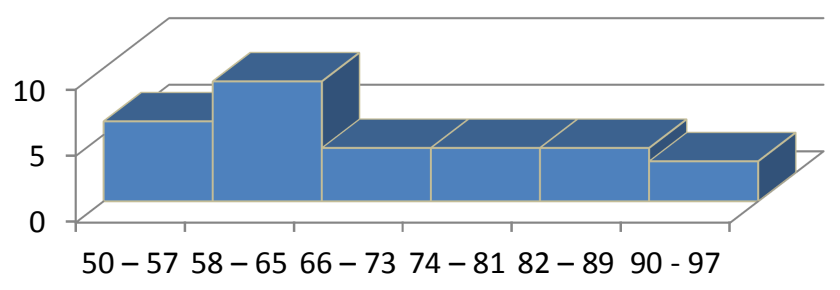

Gambar 2.Histogram Data Kelas Kontrol 
Berdasarkan gambar 2 juga dapat dilihat bahwa skor terbanyak berada pada kelas ke-2 dengan interval 58-65 yaitu sebanyak 9 orang dari keseluruhan subjek penelitian (30 orang).

Dari tabel 4 dan tabel 5tersebut terlihat bahwa terdapat perbedaan antara kelas eksperimen dan kelas kontrol, kelas eksperimen memiliki rata-rata yang lebih tinggi dari pada kelas kontrol yaitu 78,25 > 69,5 .
Sebelum pengujian normalitas dan homogenitas, terlebih dahulu dilakukan perhitungan rata-rata, standar deviasi, dan varians dari alat tes kedua sampel. Hasil perhitungan rata-rata, standar deviasi , dan varians tes akhir kelas eksperimen dan kelas kontrol dapat dilihat pada tabel 12 berikut :

Tabel 5. Hasil Perhitungan Rata-rata $(\bar{x})$, Standar Deviasi (s), dan Varians $\left(s^{2}\right)$ Tes AkhirKelas Eksperimen dan Kelas Kontrol di SMA N 2 Koto XI Tarusan

\begin{tabular}{|c|c|c|c|c|c|c|}
\hline No & Kelas Sampel & $f x$ & $\mathrm{n}$ & $\bar{x}$ & $\mathrm{~s}$ & $s^{2}$ \\
\hline 1 & Eksperimen & 2504 & 32 & 78.25 & 12,91 & 166,65 \\
\hline 2 & Kontrol & 2085 & 30 & 69,5 & 13,29 & 176,55 \\
\hline
\end{tabular}

Sumber: Pengolahan data primer 2013

Dari tabel 12 tersebut dapat dilihat bahwa pada kelas eksperimen dengan ratarata sebesar 78.25 terjadi penyimpangan 12,91 dan varians sebesar 166,65. pada kelas kontrol dengan nilai rata-rata 69,5 terjadi penyimpangan 13,29 dan varians sebesar 176,55 .

$$
\begin{array}{ll}
\mathrm{fx} & =\text { Jumlah nilai rata-rata } \\
\mathrm{n} & =\text { Jumlah siswa } \\
\bar{x} & =\text { Rata-rata nilai siswa } \\
\mathrm{s} & =\text { Standar deviasi } \\
\mathrm{s}^{2} & =\text { Varians }
\end{array}
$$

\section{PEMBAHASAN}

\section{Analisis Data}

Pengolahan data ini bertujuan untuk menguji hipotesis yang telah dirumuskan. Pengolahan data dilakukan dengan menggunakan teknik analisis seperti yang telah dirumuskan pada bagian metode penelitian. Sebelum pengujian hipotesis terlebih dahulu dilakukan uji normalitas dan uji homogenitas varians terhadap data hasil tes akhir kedua kelas sampel.

\section{Uji Normalitas Sebaran Data Tes Akhir}

Uji normalitas ini bertujuan untuk mengetahui apakah kedua sampel berasal dari populasi yang berdistribusi normal atau tidak. Uji normalitas dilakukan dengan uji liliefords. Hasil uji normalitas tes akhir kedua sampel dapat dilihat pada tabel 13 berikut ini :

Tabel 6. Hasil Uji Normalitas Tes Akhir Kelas Eksperimen danKelas Kontrol di SMA N 2 Koto XI Tarusan

\begin{tabular}{llllll}
\hline No & Kelas Sampel & $\mathrm{n}$ & $\mathrm{X}^{2}$ hitung & $\mathrm{X}^{2}$ tabel & Ket \\
1 & Eksperimen & 32 & $-113,57$ & 11,070 & Normal \\
2 & Kontrol & 30 & $-42,94$ & 11,070 & Normal \\
\hline
\end{tabular}

Sumber: Pengolahan data primer 2013

Berdasarkan uji normalitas pada tabel 13 dilihat bahwa pada kelas eksperimen di dapat $\mathrm{X}^{2}$ hitung $=-113,57<\mathrm{X}^{2}$ tabel $=$ 11,070 dan pada kelas kontrol di dapat bahwa $\mathrm{X}^{2}$ hitung $=-42,94<\mathrm{X}^{2}$ tabel $=$
11,070. Jadi dapat disimpulkan bahwa sampel berasal dari populasi yang terdistribusi normal (lihat lampiran 15 dan 16).

Uji Homogenitas Varians 
Uji homogenitas bertujuan untuk mengetahui apakah kedua kelompok data mempunyai varians yang homogen atau tidak. Hasil uji homogenitas tes akhir diantara kedua kelas sampel diperoleh harga Fhitung adalah 1,01 sedangkan Ftabel untuk taraf nyata 0,05 dengan $\mathrm{dk}$ pembilang 29 dan dk penyebut 29 adalah 1,85 (lihat lampiran 17). Dengan demikian Fhitung < Ftabel berarti kedua kelompok sampel mempunyai varians yang homogen.

Tabel 7. Hasil Uji Homogenitas Varians Tes Akhir Kelas Eksperimen dan Kelas Kontrol di SMA N 2 Koto XI Tarusan

\begin{tabular}{llllll}
\hline No & Kelas Sampel & $\mathrm{N}$ & Varians & Fhitung & Ket \\
1 & Eksperimen & 32 & 166,65 & 1,06 & Homogen \\
2 & Kontrol & 30 & 176,55 & & \\
\hline
\end{tabular}

Sumber: Pengolahan data primer 2013

Berdasarkan uji Homogenitas pada tabel 14 diketahui bahwa pada kelas eksperimen dengan $\mathrm{N}=32$ dan Varians sebesar 166,65 dan kelas kontrol dengan $\mathrm{N}=30$ dan Varians sebesar 176,55 di dapat $\mathrm{F}_{\text {hitung }}=$ 1,06 yang lebih kecil dari pada $\mathrm{F}_{\text {tabel }}=1,64$ maka sampel mempunyai varians yang Homogen.

\section{Pengujian Hipotesis Penelitian}

Uji hipotesis adalah pengujian data mengenai adanya perbedaan hasil belajar pada mata pelajaran Ekonomi yang menggunakan model pembelajaran prediction guide dengan model konvensional di SMA N 2 Koto XI Tarusan. Untuk melihat perbedaan tersebut digunakan uji kesamaan dua rata-rata yang dikemukakan oleh Sudjana (2005:241) yaitu uji t. Dari penggunaan uji $t$ didapat $t_{\text {hitung }}$ sebesar 2,63 (lihat Lampiran 18). Perumusan dalam penelitian ini adalah hasil siswa yang proses belajar mengajarnya model pembelajaran prediction guide lebih tinggi dibandingkan dengan hasil belajar siswa yang proses belajar mengajarnya menggunakan model konvensional pada mata pelajaran Ekonomi.

Penggunaan rumus rata-rata, standar deviasi, dan $t_{\text {hitung }}$ didapat nilai sebagai berikut :

Tabel 8. Hasil perhitungan Mean, Standar deviasi dan T hitung

\begin{tabular}{ll}
\hline Uraian & Besaran \\
$\mathrm{n} 1$ & 32 \\
$\mathrm{n} 2$ & 30 \\
$\bar{x} 1$ & 78.25 \\
$\bar{x} 2$ & 69.5 \\
$\mathrm{~s} 1$ & 166,65 \\
$\mathrm{~s} 2$ & 176,55 \\
$\mathrm{t}_{\text {hitung }}$ & 2,63 \\
$\mathrm{t}_{\text {tabel }}$ & 2,000 \\
\hline
\end{tabular}

Sumber: Pengolahan data primer 2013 
Dari tabel 15 diketahui nilai $\bar{x} 1=78,25$ (rata-rata nilai dengan menggunakan model pembelajaran prediction guidedan $\bar{x} 2=69,5$ (rata-rata nilai dengan menggunakan model konvensional). Hal ini berarti hasil belajar siswa yang menggunakan model pembelajaran prediction guidelebih tinggi dibandingkan dengan menggunakan model konvensional.

Pada perhitungan uji hipotesis di dapat nilai $t_{\text {hitung }}$ sebesar 2,63 dan $t_{\text {tabel }}$ sebesar 2,000 pada taraf nyata 0,05 dengan demikian $t_{0}=2,63>t_{t}=2,000$ maka hipotesis nol (Ho) ditolak, sedangkan hipotesis alternatif (Ha) diterima. Artinya hasil belajar pada kelas eksperimen lebih tinggi dari pada hasil belajar pada kelas kontrol, sehingga pembelajaran dengan menggunakan model pembelajaran prediction guide yang diterapkan sesuai dengan yang diharapkan.

Berdasarkan analisis data hasil penelitian yang telah peneliti lakukan, selanjutnya dilakukan pembahasan terhadap hasil belajar penelitian tersebut.Dari uji hipotesis diketahui bahwa hasil belajar ekonomi siswa berbeda antara yang menggunakan Strategi Prediction Guide dengan yang menggunakan pembelajaran konvensional.Hasil belajar siswa yang menggunakan StrategiPrediction Guide lebih tinggi dibandingkan hasil belajar siswa yang menggunakan konvensional.Hasil belajar dapat memperlihatkan ketuntasan siswa yang dapat dijadikan salah satu alat evaluasi oleh guru untuk mengetahui keberhasilan mengajarnya.Ini sesuai dengan pendapat Suharsimi (2010:7) yang menyatakan bahwa tujuan penilaian hasil belajar adalah untuk mengetahui siswa mana yang berhak melanjutkan pelajaran karena telah berhasil menguasai materi atau mengetahui siswa mana yang belum menguasai materi atau apakah strategi yang digunakan sudah tepat atau belum.

Dilihat dari persiapan kelas eksperimen dalam proses pembelajaran, sudah disiapkan dengan baik. Hal ini sudah terencana melalui tahap- tahap yang akanmenuntun siswa untuk menggali lebih jauh tentang konsep inflasi yang dipelajarinya.Disamping itu juga siswa mempunyai kemampuan untuk menarik kesimpulan sendiri terhadap materi yang dipelajari, sehingga siswa menjadi lebih paham dan mengerti serta dapat mengerjakan soal dengan baik dan benar.

Berdasarkan pengamatan peneliti, tingginya hasil belajar kelas eksperimen yang menggunakan strategi Prediction Guidedibandingkan kelas kontrol yang menggunakan pembelajaran konvensional dapat dilihat dari aktifitas yang dilakukan oleh siswa selama proses pembelajaran, karena pada kelas eksperimen siswa dilibatkan secara langsung dalam proses pembelajaran. Siswa diajarkan untuk berfikir kritis dan belajar secara mandiri dengan menggali materi pembelajaran tanpa harus menunggu guru untuk menjelaskannya.Berfikir kritis dan belajar secara mandiri diaplikasikan melalui pemecahan masalah-masalah yang diberikan guru. Terakhir, anggota kelompok yang mewakili kelompoknya mempresentasikan jawaban yang dibuat ke depan kelas. Anggota kelompok yang mempresentasikan adalah siswa yang ditunjuk oleh peneliti. Jadi yang menjadi kelebihan dari strategi Prediction Guidedibanding dengan pembelajaran konvensional adalah dari kegiatan siswa dalam proses belajar mengajar. Hal tersebut sesuai dengan pendapat Wina (2009:220) yang menyatakan bahwa:

(a) Dapat memahami isi pelajaran, (b) menantang kemampuan siswa, (c) meningkatkan aktivitas pembelajaran, (d) membantu siswa bagaimana mentransfer pengetahuan,

mengembangkan pengetahuan barunya, (f) memperlihatkan kepada siswa bahwa setiap mata pelajaran pada dasarnya merupakan cara berfikir, (g) menyenangkan dan disukai siswa, (h) mengembangkan kemampuan siswa untuk berfikir 
kritis, (i) memberikan kesempatan kepada siswa untuk mengaplikasikan pengetahuannya,

mengembangkan minat siswa untuk belajar secara terusmenerus.

Sedangkan pada kelas kontrol peneliti menggunakan pembelajaran konvensional, dimana peneliti memulai dengan memberikan penjelasan mengenai materi pelajaran kepada siswa secara langsung dengan menggunakan metode ceramah kemudian peneliti melakukan tanya jawab dengan siswa. Kelemahan dari pembelajaran konvensional ini adalah siswa tidak dituntut untuk menemukan dan mengolah sendiri materi pelajaran tetapi siswa hanya mengikuti materi yang telah dipersiapkan oleh peneliti.sebagaimana menurut Syamsudin dalam Sagala (2009: 179) mengemukakan bahwa dalam pembelajaran konvensional "peneliti menyajikan bahan yang telah dipersiapkan dengan rapi, sistematik dan lengkap sehingga siswa tinggal menyimak dan mencernanya secara teratur dan tertib".

Dalam proses pembelajaran seorang guru dituntut untuk dapat memilih strategi pembelajaran yang cocok dengan materi yang akan diberikan kepada siswa. Strategi pembelajaran yang digunakan oleh seorang guru akan berpengaruh terhadap kualitas dan hasil dari proses belajar. Penggunaan Strategi Prediction Guide mampu meningkatkan kemampuan siswa untuk meningkatkan penguasaan siswa terhadap suatu materi pelajaran karena ini berkaitan dengan proses ingatan dan juga menjadikan belajar lebih efisien dan mendorong keaktifan siswa dalam proses pembelajaran.

Pada dasarnya tidak ada aturan baku dalam memilih strategi pembelajaran yang akan digunakan dalam mempelajari suatu materi. Namun juga tidak ada masalah apabila seorang guru menggunakan beberapa strategi pembelajaran yang berbeda, bahwa tidak ada satupun jenis pembelajaran yang efektif untuk semua jenis materi yang akan diajarkan, melainkan dibutuhkan keterampilan guru dalam memberi variasi dan gabungan dari beberapa jenis pembelajaran yang akhirnya siswa benar-benar mampu menerima materi dan dapat meningkatkan hasil belajar.

Selama penelitian ada beberapa hambatan yang peneliti temukan. Hal ini terjadi karena peneliti belum memiliki banyak pengalaman mengajar dan Strategi Prediction Guide merupakan pengalaman baru bagi peneliti dan siswa di SMA N 2 Koto XI Tarusan. Hambatan yang ditemukan adalah penggunaan waktu yang kurang efisien dan efektif, hal ini disebabkan oleh waktu yang tersita karena penataan kelas sebelum proses pembelajaran dimulai. Pada pertemuan pertama siswa kebanyakan bingung dengan metode yang akan digunakan selama proses pembelajaran, sehingga timbul banyak pertanyaan dari siswa. Sulitnya menertibkan siswa ketika diskusi kelompok sedang berlangsung yang mengakibatkan suasana kelas menjadi tidak nyaman karena sebagian siswa tidak ikut berdiskusi denga baik.

\section{PENUTUP}

\section{Kesimpulan}

Berdasarkan penelitian yang telah dilakukan, maka dapat ditarik kesimpulan bahwa penerapan pengggunaan model pembelajaran Prediction Guide pada mata pelajaran Ekonomi memberikan hasil yang lebih baik dibandingkan dengan hasil belajar yang hanya menggunakan model Konvensional. Hal ini dapat dilihat dari rata-rata belajar siswa kelas eksperimen 78,25 sedangkan kelas kontrol 69,5. Berdasarkan perhitungan statistik yang dilakukan didapat $t_{\text {hitung }}$ memiliki nilai yang lebih besar dibandingkan dengan dengan $\mathrm{t}_{\text {tabel }}$ yaitu $\mathrm{t}_{\text {hitung }}=2,63>\mathrm{t}_{\text {tabel }}=$ 2,000 pada taraf nyata 0,05 maka hipotesis nol (Ho) ditolak sedangkan hipotesis alternatif (Ha) diterima. Dengan demikian terlihat bahwa adanya perbedaan yang signifikan hasil belajar siswa yang menggunakan model pembelajaran 
Prediction Guide dengan model konvensional pada mata pelajaran Ekonomi kelas X SMA N 2 Koto XI Tarusan.

\section{Saran}

1. Untuk mengantisipasi kesulitankesulitan dalam penggunaan model pembelajaran Prediction Guide pada mata pelajaran Ekonomi hendaknya dipersiapkan secara matang agar proses belajar mengajar dapat berjalan dengan baik.

2. Interaksi penggunaan model pembelajarn Prediction Guide pada mata pelajaran Ekonomi dapat meningkatkan hasil belajar, untuk itu guru perlu merancang pembelajaran dengan menggunakan model pembelajaran sehingga proses pembelajaran dapat lebih efektif dalam meningkatkan hasil belajar.

3. Diharapkan guru dapat memilih dan menggunakan model pembelajran yang sesuai dan dapat membangkitkan motivasi belajar siswa dan siswa merasa belajar lebih menyenangkan.

\section{DAFTAR PUSTAKA}

10.22202/economica.2014.v2.i2.228

Andre. 2007.Perbedaan Hasil Belajar Sosiologi Antara Model Pembelajaran Prediction Guide Dengan Model Konvensional Yang Dilaksanakan Di Kelas XI SMA N 2 Painan.Skripsi : UNP (Tidak diterbitkan).

Arikunto, Suharsimi.2005.Prosedur Penelitian: Suatu Pendekatan Praktik. Jakarta :PT Rineka Cipta.

Arikunto, Suharsimi.2006.Prosedur Penelitian: Suatu Pendekatan Praktik. Jakarta :PT Rineka Cipta.

Arikunto, Suharsimi.2010.dasar-dasar Evaluasi Pendidikan. Jakarta : Bumi Aksara.

Arsyad, Azhar. 2009. Media Pembelajaran. Jakarta : PT Raja Grafindo Persada.

Depdikbud. 2003. Undang-undang RI NO.20 Tahun 2003 tentang Sistem Pendidikan
Nasional. Jakarta : Lemhanas.

Dimyati \& Mudjiono. 2006. Belajar dan pembelajaran. Jakarta : Rineka Cipta.

Djamarah, Syaiful.2010.Guru Dan Anak Didik Dalam Interaksi Edukatif. Jakarta:Rineka Cipta.

Echol, John M dan Hassan Shadily. 2003. Kamus Inggris-Indonesia. Jakarta: PT. Gramedia Pustaka Utama

Hisyam, Zaini. 2007. Strategi Pembelajaran Aktif. Yogyakarta: CSD

Kurniatul.2004. Perbedaan hasil belajar fisika antara model pembelajaran Perdiction Guide dengan pembelajaran berbasis KTSP yang dilaksanakan Di kelas X SMA

Pembangunan KORPRI UNP.Skripsi : UNP (Tidak diterbitkan).

Lufri.2007. Kiat Memahami Metodologi dan Melakukan Penelitian. Padang: UNP Press

Mulyasa.2007.Kurikulum Tingkat Satuan Pendidikan.Bandung : PT Remaja Rosdakarya.

Nasution, S. 2009.Kurikulum dan Pengajaran. Jakarta: Bumi Aksara.

Oemar, Hamalik.2009. Kurikulum dan Pembelajaran. Jakarta : Bumi Aksara.

Riduwan.2006. Belajar Mudah Penelitian untuk Guru - Karyawan dan Peneliti Pemula.Bandung:Alfabeta.

Slameto.2010. Belajar dan Faktor-Faktor yang Mempengaruhinya. Jakarta: Rineka Cipta.

Sanaky, Hujair AH. 2009. Media Pembelajaran. Yogyakarta : Safiria Insania Press.

Sanjaya, Wina. 2008. Strategi Pembelajaran : Berorientasi Standar Proses Pendidikan. Jakarta : Kencana.

Sudjana (2005). Metode Statistika. Bandung : Tarsito.

Sugiyono. 2012. Metode Penelitian Pendidikan Pendekatan Kuantitatif, Kulaitatif, dan $R \& D$. Bandung : Alfabeta 
Miky Mardianto 